\title{
Improving Concentration of Healthy Fatty Acids in Milk, Cheese and Yogurt by Adding a Blend of Soybean and Fish Oils to the Ration of Confined Dairy Cows
}

\author{
Gerardo Antonio Gagliostro1, Liliana Elisabet Antonacci1, Carolina Daiana Pérez ${ }^{2,3}$, \\ Luciana Rossetti2 ${ }^{2}$, Augusto Carabajal ${ }^{4}$
}

\author{
${ }^{1}$ Instituto Nacional de Tecnología Agropecuaria (INTA), Estación Experimental Balcarce, Area de Producción Animal, Balcarce, \\ Argentina \\ ${ }^{2}$ Instituto de Tecnología de Alimentos (ITA), CNIA INTA, Castelar, Argentina \\ ${ }^{3}$ Consejo Nacional de Investigaciones Científicas y Técnicas (CONICET), Buenos Aires, Argentina \\ ${ }^{4}$ Establecimiento Agroindustrial Talar, Laguna del Sauce, Departamento de Maldonado, Punta del Este, República Oriental del \\ Uruguay \\ Email: gagliostro.gerardo@inta.gob.ar
}

How to cite this paper: Gagliostro, G.A., Antonacci, L.E., Pérez, C.D., Rossetti, L. and Carabajal, A. (2020) Improving Concentration of Healthy Fatty Acids in Milk, Cheese and Yogurt by Adding a Blend of Soybean and Fish Oils to the Ration of Confined Dairy Cows. Open Journal of Animal Sciences, 10, 182-202.

https://doi.org/10.4236/ojas.2020.101010

Received: November 6, 2019

Accepted: January 18, 2020

Published: January 21, 2020

Copyright $\odot 2020$ by author(s) and Scientific Research Publishing Inc. This work is licensed under the Creative Commons Attribution International License (CC BY 4.0).

http://creativecommons.org/licenses/by/4.0/

c) (†) Open Access

\begin{abstract}
Compared to pasture based sistems, milk produced in confined dairy systems is characterized by a high saturated fat (SF) content with a lower concentration of healthy fatty acids (FA) such as vaccenic (VA, trans-11 $1 \mathrm{C}_{18: 1}$ ), conjugated li-

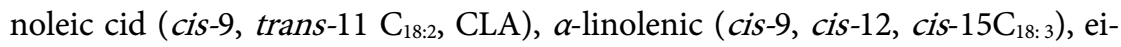
cosapentaenoic (EPA, $\mathrm{C}_{20: 5}$ ) and docosahexaenoic $\left(\mathrm{DHA}, \mathrm{C}_{22: 6}\right.$ ) whose presence in milk and dairy products can be increased by feeding polyunsaturated FA (PUFA). The aim of the study was to determine the differences in milk composition and FA profile between a regular (Reg) milk (Reg-Milk), a Reg-Dambo type cheese (Reg-DCh) and a Reg yogurt (Reg-Yog) with that obtained after including a blend (7:1) of soybean (SO) and fish (FO) oils in the total mixed ration (TMR) of lactating dairy cows. The experiment was carried out at the Talar Farm located at Laguna del Sauce, Maldonado Department, Punta del Este, Uruguay Republic during a period of 30 experimental days using a single production batch of 29 Holstein cows. Within this batch, one group of 8 cows ( $1.88 \pm 0.99$ calves) in early lactation (135 \pm 19 days postpartum) was selected to individually measure milk yield and composition. During the first 7 days of the experiment, cows were fed a TMR without oil-blend inclusion to obtain the Reg-Milk, Reg-DCh and Reg-Yog. From the $8^{\text {th }}$ day onwards, the oil blend was added to the TMR at $4 \%$ DM (1.0 $\mathrm{kg}$ oil blend $\operatorname{cow}^{-1}$ day $^{-1}$ ) and after 23 days of feeding, the modified milk
\end{abstract}


(Mod-Milk) was analyzed and collected to elaborate the modified Dambo-type cheese (Mod-DCh) and Mod-yogurt (Mod-Yog). Milk yield was recorded daily in the selected 8 cows and milk composition was determined over two consecutive days prior to the start of blend-oil supply (Reg-Milk) and at the end of oil supplementation (Mod-Milk) on days $29^{\text {th }}$ and $30^{\text {th }}$. Milk-tank samples of Reg-Mi and Mod-Mi were also collected and analyzed for chemical composition and milk FA profile. Cheese and yogurt were assayed for its FA profile. Differences in milk yield and composition and in the FA profile before and after oil-feeding were stated using the Student T-test for paired observations. Milk production $\left(\mathrm{kg} \cdot \mathrm{cow}^{-1} \cdot \mathrm{day}^{-1}\right)$ slightly $(-6.7 \%)$ decreased $(P$ $<0.03$ ) from 36.89 (before) to 34.69 after oil feeding. Milk fat content de-

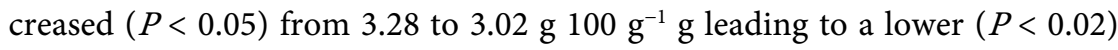
yield $\left(\mathrm{kg} \cdot \mathrm{cow}^{-1} \cdot \mathrm{day}^{-1}\right)$ of fat corrected milk $(4 \% \mathrm{FCM})$ from 32.83 (before) to

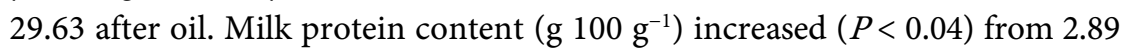
(before) to 3.08 (after) oil feeding $(+5.92 \%)$ a result confirmed $(P<0.01)$ in samples taken from the tank. Milk protein output $\left(1.07 \mathrm{~kg} \cdot \mathrm{cow}^{-1} \cdot \mathrm{day}^{-1}\right)(P<$ 0.96), lactose $(P<0.65)$ and total solid $(P<0.38)$ contents were not affected. Concentration of non-fat solids (NFS) tended $(P<0.08)$ to increase from 8.50

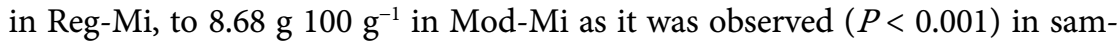

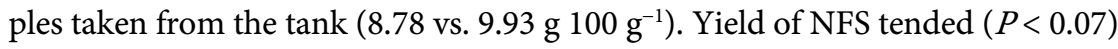
to decrease from 3.14 to $3.01 \mathrm{~kg} \cdot \mathrm{cow}^{-1} \cdot \mathrm{day}^{-1}$ after oil supply. Content of atherogenic $\mathrm{FA}\left(\mathrm{C}_{12: 0}\right.$ to $\left.\mathrm{C}_{16: 0}\right)$ was significantly $(P<0.064)$ reduced $(-10.29 \%)$ from

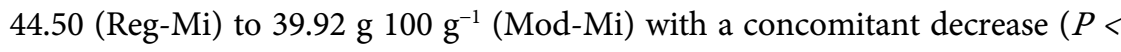
0.10 ) in the atherogenic index (AI) from 2.45 (Reg-Mi) to 2.03 (Mod-Mi). Concentration (g $100 \mathrm{~g}^{-1} \mathrm{FA}$ ) of elaidic (trans-9 $\mathrm{C}_{18: 1}$ ) and trans-10 $\mathrm{C}_{18: 1}$ FA was low in Reg-Mi ( 0.22 and 0.34 respectively) but tended $(P<0.11)$ to increase in Mod-Mi (0.43 and 0.95). Concentration ( $100 \mathrm{~g}^{-1} \mathrm{FA}$ ) of VA resulted higher $(+110 \%, P<0.039)$ in Mod-Mi $(2.42)$ compared to Reg-Mi (1.15). Total CLA content ( $\left.100 \mathrm{~g}^{-1} \mathrm{FA}\right)$ increased $(P<0.036)$ from 0.66 in Reg-Mi to 1.36 in Mod-Mi (+106\%). Levels $\left(\mathrm{g} 100 \mathrm{~g}^{-1}\right)$ of $\alpha$-linolenic were higher $(P<0.004)$ in Reg-Mi (0.34) compared to Mod-Mi (0.29). The omega-6/omega-3 ratio was not changed $(P<0.13)$ averaging 5.98 in $\mathrm{R}-\mathrm{Mi}$ and 7.18 in $\mathrm{M}-\mathrm{Mi}$. Oleic acid (cis-9 $\left.\mathrm{C}_{18: 1}\right)$ content $\left(\mathrm{g} 100 \mathrm{~g}^{-1}\right)$ remained unchanged $(P<0.504)$ averaging 21.99 in Reg-Mi and 22.86 in Mod-Mi. Composition of FA of the Mod-DCh was highly correlated $\left(\mathrm{R}^{2}=0.999\right)$ with FA profile from its original Mod-Mi. A serving of the M-DCh $(30 \mathrm{~g})$ theoretically involved a $12.1 \%$ reduction in total fat consumption with $16.9 \%$ less in SF intake compared to the Reg-Ch. A serving of the M-DCh could putatively increase total CLA consumption by $72.7 \%$ compared to the Reg-DCh. Compared to Reg-Yo, a portion $(178 \mathrm{~g})$ of the Mod-Yo could increase (69.4\%) total CLA intake. The nutritional value of milk fat was improved by feeding a blend of PUFA oils to confined dairy cows and the consumption of the mofified dairy products obtained could promote a lower intake of the potentially atherogenic saturated FA and some increase in healthy FA ingestion.

\section{Keywords}

Dairy Cows, Oil, Saturated Fat, Conjugated Linoleic Acid, Cheese, Yogurt 


\section{Introduction}

The growing incidence in the modern society of noncommunicable cardiovascular and chronic diseases plus the increase of cases of childhood obesity implies a significant economic and social burden for the states and creates the need to produce food capable of mitigating these risks. Milk and its derivatives represent the largest contribution in the consumption of saturated fatty acids (SFA), which represents a potential risk of chronic cardiovascular diseases, obesity and metabolic syndrome [1] [2] [3]. The potentially unhealthy milk SFA are lauric $\left(\mathrm{C}_{12: 0}\right)$, myristic $\left(\mathrm{C}_{14: 0}\right)$ and palmitic $\left(\mathrm{C}_{16: 0}\right)$ for their putative atherogenic role when consumed in excess [4]. Those SFA have been associated with the risk of cardiovascular disease [5] [6]. As a counterpart, milk and dairy are the main natural foods containing the conjugated linoleic acids (CLA) with promising cardioprotective [3] and antitumor [7] [8] [9] properties.

Experimental evidence of the CLA's contribution to cancer patients is still insufficient but both, cis-9, trans-11 $\mathrm{C}_{18: 2}$ CLA (rumenic acid) and trans-10, cis-12 $\mathrm{C}_{18: 2}$ CLA, have shown promising effects in animal studies or in in vitro cell cultures with different tumor lines [7] [8] [9].

Feeding with conventional foods would not allow sufficient daily intake of CLA to attain expression of its potential biochemical, molecular and physiologically preventive effects on cardiovascular pathologies [8], diabetes [10] [11], atherosclerosis [12], different types of cancer [13] [14], hypertension [8], obesity [8] [15] or anti-inflammatory effects [16] [17]. From the analysis of nine studies in humans, it was concluded that the chronic consumption of a milk with a modified FA profile was beneficial for the cardiovascular health of normal and hypercholesterolemic human individuals [3]. In another study, the consumption of CLA from dairy products was associated with a lower risk of myocardial infarction in a population of 1813 cases of first non-fatal acute infarction and 1813 control individuals grouped by age, sex and area of residence [18].

The inclusion of oils rich in polyunsaturated FA (PUFA) in the ration of dairy cows allows modifying the milk and dairy FA profile in a sense that may be favorable to human health [19] [20]. In dairy cows, intake of linoleic acid (cis-9, cis-12 $\mathrm{C}_{18: 2}$ ) contained in $\mathrm{SO}$ is a quick and effective tool to inhibit the mammary synthesis of the potentially atherogenic FA and to increase the milk CLA content [21].

Inclusion of FO in the ration as a source of EPA and DHA inhibits the biohydrogenation of VA (the main CLA precursor) to stearic acid [21] and moderate amounts of FO do not appear to affect the rumen environment or fiber digestión [22]. The aim of the study was to determine the effect of feeding a blend of PUFA oils on FA composition of milk, Dambo type cheese and yogurt specifically concerning those FA that are beneficial to human health.

\section{Materials and Methods}

\subsection{Cows and Diets}

The trial lasted 30 days, from June 24 to July 23, 2019 and was carried out at the 
Agroindustrial Complex located in Laguna del Sauce, Route $12 \mathrm{~km} \mathrm{10,}$ Department of Maldonado, Punta del Este (Uruguay Republic). A single production-batch composed by 29 confined Holstein cows was used from which one subgroup of 8 cows $(1.88( \pm 0.99)$ calves $)$ in early lactation (135 \pm 19 days postpartum) were selected for individual measurements of milk yield and composition.

During a pre-experimental period of 7 days, the cows were fed a basal TMR (Table 1) without supplementary oils in order to asses milk yield and composition at the beginning of the trial (Reg-Milk). A regular Dambo type cheese (R-DCh) and yogurt (R-Yo) were manufactured using the Reg-Milk.

From the $8^{\text {th }}$ day onwards, a blend $(7: 1 \mathrm{w} / \mathrm{w})$ of $\mathrm{SO}$ and FO was added to the TMR at $4 \%$ DM delivering about 0.875 and $0.125 \mathrm{~kg} \cdot \mathrm{cow}^{-1} \cdot \mathrm{day}^{-1}$ respectively. The oil-blend was mixed with the non-forage components of the TMR prior to the incorporation into the mixer and subsequent mixed with the ryegrass silage. The deodorized FO (99.5\% DM, AD-1, Omega Sur Laboratories, Mar del Plata, Argentina) presented a density of $0.925 \mathrm{~g} / \mathrm{cm}^{3}$ (IRAM 5504), a peroxide index of 1.91 meq. $\mathrm{O}^{2} / \mathrm{kg}$ of oil (AOCS Cd 8-53) and absence of Salmonella. The FA profile of the FO was determined by gas chromatography with FID detection and is presented in Table 2.

Table 1. Type and cost of ingredients used to formulate the total mixed ration of the experiment.

\begin{tabular}{|c|c|c|c|}
\hline Ingredient & $\% \mathrm{DM}^{(1)}$ & $\%$ as fed & $\operatorname{Cost}^{(2)}$ \\
\hline Cracked corn grain & 16.84 & 8.22 & 180 \\
\hline Ryegrass silage & 47.45 & 74.65 & 35 \\
\hline Pelletized soybean meal & 15.49 & 7.61 & 360 \\
\hline Mineral-vitamin premix $\left(\mathrm{Nutral}^{\mathrm{TM}}\right)$ & 2.72 & 1.18 & 500 \\
\hline Dried distillery grains (DDGS) & 9.36 & 4.26 & 215 \\
\hline Cracked sorghum grain & 8.14 & 4.09 & 140 \\
\hline
\end{tabular}

${ }^{(1)} \mathrm{DM}=$ dry matter. ${ }^{(2)}$ Values are expressed in US dollars per Ton "as fed".

Table 2. Fatty acid (FA) composition of the fish oil used in the experiment.

\begin{tabular}{cc}
\hline $\mathrm{FA}$ & ${\mathrm{g} 100 \mathrm{~g}^{-1} \mathrm{FA}}^{\mathrm{C}_{18: 3 \mathrm{n} 3}}$ \\
$\mathrm{C}_{18: 4 \mathrm{n} 3}$ & 0.88 \\
$\mathrm{C}_{20: 3 \mathrm{n} 3}$ & 0.40 \\
$\mathrm{C}_{20: 4 \mathrm{n} 3}$ & 0.39 \\
$\mathrm{C}_{20: 5 \mathrm{n} 3 \mathrm{EPA}}$ & 0.71 \\
$\mathrm{C}_{21: 5 \mathrm{n} 3}$ & 7 \\
$\mathrm{C}_{22: 5 \mathrm{n} 3 \mathrm{DPA}}$ & 0.62 \\
$\mathrm{C}_{22: 6 \mathrm{n} 3 \mathrm{DHA}}$ & 1.01 \\
Total n-3 FA & 16.99 \\
Total n-6 FA & 28 \\
Polyunsaturated FA & 2.05 \\
Free FA & 30.05 \\
& 0.24 \\
\hline
\end{tabular}




\subsection{Samples Collection and Analysis}

In the subgroup of 8 selected cows, milk production was daily and individually recorded during the whole trial. Milk composition was measured on the individual milk samples (8 cows) and in samples taken from the collecting tank (29 cows) on days $6^{\text {th }}$ and $7^{\text {th }}$ (Regular) and $29^{\text {th }}$ and $30^{\text {th }}$ of the trial after oil delivery to obtain the modified products (Mod-Milk, Mod-Dch and Mof-Yo).

On each day, a sample of milk was taken from the morning $(50 \mathrm{ml})$ and the afternoon $(50 \mathrm{ml})$ milkings to analyze chemical composition (fat, protein, lactose, non-fat solids (NFS) and total solids (TS)) by infrared spectrophotometry (MilkoScanTM Minor; FOSS Electric, Hilleroed Hillerod, Denmark) according to ISO 9622 IDF 141 (2013). Milk samples collected from the tank were also assayed for FA composition. After 23 days of oil-blend feeding, the Mod-Milk was analyzed for chemical composition an collected to manufacture the Mof-DCh and Mod-Yo.

\subsection{Analysis of Fatty Acid Profile in Milk and Dairy Products}

Milk fat was extracted following the method described in [23]. Methyl esters of FA (FAME) were prepared by base-catalysed methanolysis of the glycerides according to the ISO-IDF procedure (2002). Analysis of FAME in hexane was performed on a gas-liquid chromatograph (Varian CP3800, Walnut Creek, CA, USA) fitted with a flame ionization detector. The FAME profile was determined by split injection (1:100) onto a CP-Sil 88 fused silica capillary column $(100 \mathrm{~m} \times$ $0.25 \mathrm{~mm}$ i.d., $0.20 \mu \mathrm{m}$ film thickness, Varian CP7489) using a gradient temperature programme. The column oven was held at $45^{\circ} \mathrm{C}$ for $4 \mathrm{~min}$, then increased from $45^{\circ} \mathrm{C}$ to $165^{\circ} \mathrm{C}$ at $13^{\circ} \mathrm{C} / \mathrm{min}$ and held for $35 \mathrm{~min}$ and finally from $165^{\circ} \mathrm{C}$ to $215^{\circ} \mathrm{C}$ at $4^{\circ} \mathrm{C} / \mathrm{min}$ and held for $30 \mathrm{~min}$. The total run time was $90 \mathrm{~min}$. The carrier gas was helium and was held at a constant flow of $1.0 \mathrm{~mL} / \mathrm{min}$. The injector and detector temperatura were $250^{\circ} \mathrm{C}$. Fatty acids were identified by comparing relative retention times with individual fatty acids standard (PUFA-2 Animal Source; Grain Fatty acid Methyl Ester Mix; Octadecadienoic acid conjugated methyl ester; trans-11-Vaccenic Methyl Ester; cis-11-Vaccenic Methyl Ester; trans-9-Elaidic Methyl Ester; 37-Component FAME mix (Sigma-Aldrich, USA) and GLC 481B (NuChek Prep. Inc. Elysian, MN, USA). Analytical results are expressed as percentages of total FA. The tank-milk samples were also collected during days $6^{\text {th }}$ and $7^{\text {th }}$ (Basal) and $29^{\text {th }}$ and $30^{\text {th }}$ (Final) and the same procedure was applied.

\subsection{Statistical Analysis}

The difference in milk production, chemical composition and milk FA profile was analyzed through the Student's T test for paired observations.

\section{Results and Discussion}

The TMR averaged $43.26 \%$ DM with $17.62 \%$ crude protein, $35.91 \%$ neutral de- 
tergent fiber (NDF), $2.74 \mathrm{Mcal} \cdot \mathrm{kg}^{-1} \mathrm{DM}$ of estimated metabolizable energy content and a forage:concentrate ratio of $47: 53$. It was offered at $4.55 \%$ of the average live weight of the production-batch (29 cows) and thoroughly consumed by cows which implied a daily allowance of $25 \mathrm{~kg} \mathrm{DM} \mathrm{cow}^{-1} \cdot$ day $^{-1}$ equivalent to 57.8 kg TMR as fed.

\subsection{Milk Yield and Composition}

The yield of 4\%FCM decreased after oil supplementation (-11.9\%) as the combined effects of both, a slight decrease $(P<0.03)$ in milk production and a lower milk fat content (Table 3). Supplementation with unsaturated lipids generally has neutral effects on the production of 4\%FCM both in confined [25] and in pasture based diets [26]. Feeding unsaturated lipids to lactating dairy cows neither increase nor negatively affect milk production [25] [26]. Negative effects on milk production were also not observed after feeding unprotected vegetable oils to confined dairy cows with a high frequency of favorable effects on milk yield

Table 3. Milk yield and composition in confined dairy cows before (Initial) and 23 days after (Final) including a blend of soybean oil $\left(0.875 \mathrm{~kg} \cdot \mathrm{cow}^{-1} \cdot \mathrm{day}^{-1}\right)$ and fish oil $(0.125$ $\left.\mathrm{kg} \cdot \mathrm{cow}^{-1} \cdot \mathrm{day}^{-1}\right)$ in the total mixed ration.

\begin{tabular}{|c|c|c|c|c|c|}
\hline Selected cows ${ }^{(1)}$ & Initial (a) & Final (b) & $\begin{array}{l}\text { Difference } \\
\text { (a)-(b) }\end{array}$ & $\Delta \%^{(2)}$ & $P<{ }^{(3)}$ \\
\hline Milk yield, $\mathrm{kg} \cdot \mathrm{cow}^{-1} \cdot \mathrm{day}^{-1}$ & $36.89( \pm 5.49)$ & $34.69( \pm 5.48)$ & $2.20( \pm 2.13)$ & -6.66 & 0.03 \\
\hline $4 \%$ FCM yield, $\mathrm{kg} \cdot \mathrm{cow}^{-1} \cdot \mathrm{day}^{-1}$ & $32.83( \pm 4.39)$ & $29.63( \pm 5.28)$ & $3.21( \pm 2.73)$ & -11.86 & 0.02 \\
\hline Milk fat content, $\mathrm{g} 100 \mathrm{~g}^{-1}$ & $3.28( \pm 0.42)$ & $3.02( \pm 0.39)$ & $0.27( \pm 0.29)$ & -9.24 & 0.05 \\
\hline Milk fat yield, , $\mathrm{kg} \cdot \mathrm{cow}^{-1} \cdot \mathrm{day}^{-1}$ & $1.21( \pm 0.18)$ & $1.05( \pm 0.22)$ & $0.16( \pm 0.14)$ & -16.68 & 0.03 \\
\hline Milk protein content, g $100 \mathrm{~g}^{-1}$ & $2.89( \pm 0.12)$ & $3.08( \pm 0.10)$ & $0.10( \pm 0.25)$ & 5.92 & 0.04 \\
\hline Milk protein yield, $\mathrm{kg} \cdot \mathrm{cow}^{-1} \cdot \mathrm{day}^{-1}$ & $1.07( \pm 0.16)$ & $1.07( \pm 0.15)$ & - & - & 0.96 \\
\hline Lactose content, g $100 \mathrm{~g}^{-1}$ & $4.87( \pm 0.10)$ & $4.86( \pm 0.10)$ & $0.02( \pm 0.08)$ & -0.32 & 0.65 \\
\hline Lactose yield, $\mathrm{kg} \cdot \operatorname{cow}^{-1} \cdot \mathrm{day}^{-1}$ & $1.80( \pm 0.28)$ & $1.69( \pm 0.29)$ & $0.11( \pm 0.10)$ & -6.97 & 0.02 \\
\hline Total solid content, g $100 \mathrm{~g}^{-1}$ & $11.78( \pm 0.47)$ & $12.01( \pm 0.81)$ & $-0.23(0.64)$ & +1.66 & 0.38 \\
\hline Total solid yield, $\mathrm{kg} \cdot \mathrm{cow}^{-1} \cdot \mathrm{day}^{-1}$ & $4.34( \pm 0.60)$ & $4.17( \pm 0.75)$ & $0.17( \pm 0.46)$ & -5.09 & 0.37 \\
\hline Non-fat solid content, g $100 \mathrm{~g}^{-1}$ & $8.50( \pm 0.12)$ & $8.68( \pm 0.11)$ & $0.18( \pm 0.22)$ & +2.06 & 0.08 \\
\hline Non-fat solid yield, $\mathrm{kg} \cdot \mathrm{cow}^{-1} \cdot \mathrm{day}^{-1}$ & $3.14( \pm 0.48)$ & $3.01( \pm 0.47)$ & $0.13( \pm 0.15)$ & -4.38 & 0.07 \\
\hline \multicolumn{6}{|l|}{ Milk tank samples ${ }^{(4)}$} \\
\hline Milk fat content, $g 100 \mathrm{~g}^{-1}$ & $3.43( \pm 0.03)$ & $3.26( \pm 0.08)$ & $0.17( \pm 0.11)$ & -5.40 & 0.11 \\
\hline Milk protein content, g $100 \mathrm{~g}^{-1} \mathrm{~g}$ & $3.15( \pm 0.01)$ & $3.28( \pm 0.03)$ & $0.12( \pm 0.02)$ & +3.76 & 0.01 \\
\hline Lactose content, g $100 \mathrm{~g}^{-1}$ & $4.88( \pm 0.01)$ & $4.90( \pm 0.01)$ & $0.01( \pm 0.01)$ & +0.27 & 0.06 \\
\hline Total solid content, g $100 \mathrm{~g}^{-1} \mathrm{~g}$ & $12.23( \pm 0.03)$ & $12.23( \pm 0.07)$ & - & +0.27 & 0.94 \\
\hline Non-fat solid content, g $100 \mathrm{~g}^{-1} \mathrm{~g}$ & $8.78( \pm 0.01)$ & $8.93( \pm 0.03)$ & $0.14( \pm 0.02)$ & +1.61 & 0.00 \\
\hline
\end{tabular}

${ }^{(1)}$ Eight animals individually monitored; ${ }^{(2)}$ Relative changes (\%) compared to Initial values. ${ }^{(3)}$ Statistical significance of the difference $(\mathrm{a}-\mathrm{b})$, Student's t-test for paired differences. ${ }^{(4)}$ Obtained from the production-batch of 29 milked cows. $4 \% \mathrm{FCM}=$ milk corrected at $4 \%$ fat. 
[27]. Feeding SO at $2.9 \%( \pm 1.2)$ of total DM intake did not affect milk production in the experiments reviewed by [28] and also when oil was fed at $3.5 \%$ to $5 \%$ of DM intake [29] [30] [31].

These results were not confirmed in the present work since the inclusion of $\mathrm{SO}$ at $3.5 \%$ of DM intake decreased milk production. In our previous trial using corn-silage as forage source in the TMR, the inclusion of SO at 3\% of DM intake increased milk production [20]. In the present experiment, the shift from corn to pasture-silage could probably explain the observed slight decrease $(-6.7 \%)$ in milk production (Table 3) owing to a lower palatability of the ryegras silage linked to its little bitter taste.

Intake of supplementary PUFA contained in the SO-FO blend reduced $(P<$ $0.05)$ milk fat concentration by $9.24 \%$. A lower milk fat content $(-5.4 \%)$ was also detected $(P<0.11)$ in samples taken from the tank reflecting an overall negative effect of oil intake over the total herd. Milk fat content decrease (9.24\% to 5.4\%) was close to the average value of $8 \%$ reported for grazing dairy cows [26] but lower than the $28.6 \%$ observed in our previous work using the SO $(0.72$ $\left.\mathrm{kg} \cdot \mathrm{cow}^{-1} \cdot \mathrm{day}^{-1}\right)$, micro-algae $\left(0.144 \mathrm{~kg} \cdot \mathrm{cow}^{-1} \cdot \mathrm{day}^{-1}\right)$ combination [20].

The presence of DHA in the FO (a potent inhibitor of de novo mammary lipid synthesis) plus the ruminal generation of certain FA such as trans-10 $\mathrm{C}_{18: 1}$ and its subsequent transfer to the mammary gland contribute to explain the fall in milk fat content (Table 3). A direct relationship between increasing levels of trans-10 $\mathrm{C}_{18: 1}$ in milk and the reduction of de novo mammary synthesis has been reported [32]. The presence of trans-10 $\mathrm{C}_{18: 1}$ has been associated with dysfunctions in the activity of the lipoprotein lipase (LPL) and stearyl CoA desaturase (SCD) enzymes that are involved in fat synthesis thus causing a decrease in milk fat content [33]. In the present work, both the concentration of trans-10 $\mathrm{C}_{18: 1}$ and that of DHA in milk were low, contributing in part to explain the moderate depressant effect observed on milk fat concentration. In a previous grazing experiment, feeding SO combined or not with FO strongly reduced milk fat content ( -19 to -27\%) compared to the pre-supplementation record [34].

The inhibition of the de novo FA mammary synthesis with the lower total concentration of SFA in milk (Table 4) partially contributes to explaining the milk fat content reduction. The decrease in FA synthesized de novo (Table 4) was not apparently compensated by a correlative increase in the mammary uptake of supplementary preformed FA contained in SO and FO and milk fat content decreased. It is worth noting that the observed fat reduction (Table 3) occurred in part at the expense of the amount of the hypercholesterolemic FA (Table 4). This fact potentially improves the healthy value of milk and contributes to decrease its atherogenic potential and the atherogenicity index of the Mod-Milk (Table 4).

After oil-blend intake, milk protein concentration slightly (+5.92\%) increased $(P<0.04)$ an effect that was also observed in milk samples taken from the tank (Table 3 ). Synthesis of milk protein can be limited by energy availability and a 
Table 4. Milk fatty acid (FA) composition in regular (Reg-Milk) and modified (Mod-Milk) milks after including a blend of soybean $\left(0.875 \mathrm{~kg} \cdot \mathrm{cow}^{-1} \cdot \mathrm{day}^{-1}\right)$ and fish $\left(0.125 \mathrm{~kg} \cdot \mathrm{cow}^{-1} \cdot \mathrm{day}^{-1}\right)$ oils to the ration of confined dairy cows.

\begin{tabular}{|c|c|c|c|c|}
\hline $\begin{array}{l}\text { Fatty Acid } \\
\text { g/100g FA }\end{array}$ & Reg-Milk & Mod-Milk & $\Delta \%^{(1)}$ & $P<<^{(2)}$ \\
\hline $\mathrm{C}_{4: 0}$ & 2.21 & 2.04 & -8.04 & 0.194 \\
\hline $\mathrm{C}_{6: 0}$ & 1.81 & 1.55 & -14.36 & 0.104 \\
\hline $\mathrm{C}_{8: 0}$ & 1.20 & 1.04 & -13.80 & 0.063 \\
\hline $\mathrm{C}_{10: 0}$ & 2.74 & 2.41 & -12.11 & 0.073 \\
\hline $\mathrm{C}_{12: 0}$ & 3.12 & 2.89 & -7.26 & 0.158 \\
\hline $\mathrm{C}_{14: 0}$ & 10.68 & 10.05 & -5.93 & 0.230 \\
\hline $\mathrm{C}_{16: 0}$ & 30.70 & 26.98 & -12.12 & 0.029 \\
\hline$\Sigma \mathrm{C}_{12: 0-\mathrm{C} 16: 0}$ & 44.50 & 39.92 & -10.29 & 0.064 \\
\hline $\mathrm{C}_{18: 0}$ & 9.64 & 10.17 & +5.44 & 0.321 \\
\hline $\mathrm{C}_{18: 1 \mathrm{t} 9}$ & 0.22 & 0.43 & +100.23 & 0.015 \\
\hline $\mathrm{C}_{18: 1 \mathrm{t} 10}$ & 0.34 & 0.95 & +178.53 & 0.109 \\
\hline $\mathrm{C}_{18: 1}$ t11 (vaccenic acid) & 1.15 & 2.42 & +110.23 & 0.004 \\
\hline $\mathrm{C}_{18: 1 \mathrm{l} \text { c9 (oleic acid) }}$ & 21.99 & 22.86 & +3.97 & 0.504 \\
\hline $\mathrm{C}_{18: 2 \text { c9 c12 (linoleic acid) }}$ & 2.33 & 2.42 & +3.64 & 0.392 \\
\hline $\mathrm{C}_{18: 3 \text { c89 c12 c15 (linolenic acid) }}$ & 0.34 & 0.29 & -14.90 & 0.004 \\
\hline $\mathrm{C}_{18: 2 \text { cis-9, trans }-11}, \mathrm{CLA}$ & 0.66 & 1.34 & +102.85 & 0.039 \\
\hline 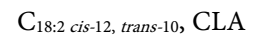 & - & 0.02 & & \\
\hline Total CLA & 0.66 & 1.36 & +106.36 & 0.036 \\
\hline Saturated FA & 65.27 & 60.55 & -7.24 & 0.046 \\
\hline Monounsaturated FA & 28.26 & 31.65 & +12.00 & 0.102 \\
\hline Polyunsaturated FA & 3.68 & 4.32 & +17.57 & 0.016 \\
\hline Total Omega 3 (n-3) & 0.43 & 0.36 & -16.26 & 0.058 \\
\hline Total Omega 6 (n-6) & 2.58 & 2.60 & +0.59 & 0.847 \\
\hline Atherogenic index & 2.45 & 2.03 & -17.23 & 0.102 \\
\hline$n-6 / n-3$ & 5.98 & 7.18 & +20.10 & 0.129 \\
\hline
\end{tabular}

${ }^{(1)}$ Relative FA changes (\%) compared to values observed in the Reg-Milk, $(-)=$ decrease, $(+)=$ increase. ${ }^{(2)}$ Student $\mathrm{t}$ Test $t$ for paired observations.

reduced milk fat content (Table 3) could have spared energy improving the energy status of the cows. As the consequence of a lower milk production after oil supplementation, milk protein output remained constant $(P<0.96)$ averaging $1.07 \mathrm{~kg}$ protein $\mathrm{cow}^{-1} \cdot \mathrm{day}^{-1}$ (Table 3 ). The increase in milk protein content is a desirable effect not observed in our previous work using a mix of $\mathrm{SO}$ and microalgae [20]. A higher protein concentration improves the industrial aptitude of milk for cheese making and determines the speed and quality of coagulation. Under grazing conditions, lipid supplementation does not usually affect milk 
protein content [26] [35] but in confined feeding systems, milk protein concentration is systematically affected [25] [34]. The effect of supplementation with unprotected lipids on milk protein was unfavorable in $71 \%$ of the cases analyzed by [27] and is associated with a reduction in casein synthesis [37] [38]. The neg-

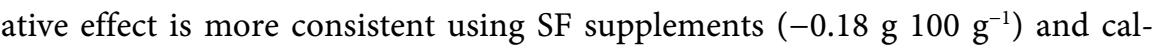

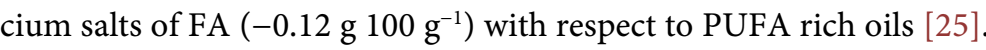

Lactose and TS contents were not significantly affected after oil intake (Table $3)$. As a consequence of the increase in the milk protein content, concentration of NFS tended $(P<0.08)$ to increase after oil intake and resulted higher $(+1.61 \%)$ in milk samples obtained from the tank (Table 3 ).

\subsection{Milk Fatty Acid Profile}

The changes observed in milk FA composition (Table 4) after feeding the oil blend may be explained by the increase in the mammary uptake of plasma triglycerides when adding supplementary PUFA to the ration and confirms the existence of a great plasticity in milk FA composition [21] [28].

The absence of a net depressant effect $(\mathrm{P}=0.19)$ of supplementary PUFA on butyric acid $\left(\mathrm{C}_{4: 0}\right)$ content of Mod-Milk (Table 4) was also observed in our previous study [20] being a result frequently reported [28]. This FA is only found in ruminant milk and has shown antineoplasic effects inhibiting the development of mammary carcinoma in rats [39] and hence is considered to play a potential beneficial role in human health.

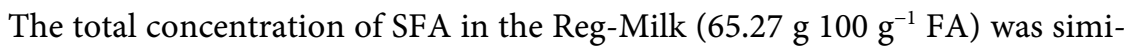

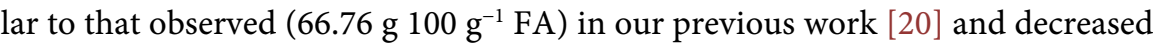
$(P<0.046)$ to $60.55 \mathrm{~g} 100 \mathrm{~g}^{-1} \mathrm{FA}$ in the Mod-Milk obtained after adding the SO-FO blend to the TMR (Table 4). This reduction in SFA was however less than the $17.7 \%$ obtained when SO was combined with microalgae [20]. The result can be considered of interest since the excessive consumption of SFA is considered unhealthy and associated with raised blood cholesterol levels increasing the risk of developing heart disease. There is evidence that substituting SFA with PUFA's reduces the risk of coronary heart disease. The SFA reduction was coupled to a concomitant increase $(+12 \%)$ in concentration of monounsaturated

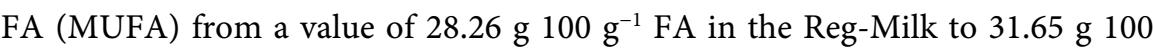
$\mathrm{g}^{-1}$ FA in the Mod-Milk (Table 4). The increase was however less than obtained in our previous trial $(37 \%)$ when a mix of SO-microalgae was included in the TMR [20].

Concentration of PUFA (g $\left.100 \mathrm{~g}^{-1} \mathrm{FA}\right)$ was also increased $(P<0.016)$ by $17.6 \%$ from a basal value of 3.68 in Reg-Milk to 4.32 in the Mod-Milk. This increase resulted lower than the $36 \%$ obtained in our previous work using the SO-microalgae mix [20].

Compared to Reg-Milk, the Mod-Milk showed a moderate (-10.29\%) but significant $(P<0.064)$ decrease $(-4.58 \mathrm{~g}$, Table 4$)$ in total concentration of the potentially atherogenic FA $\left(\mathrm{C}_{12: 0}\right.$ to $\left.\mathrm{C}_{16: 0}\right)$ promoting a healthier milk [4]. The re- 
duction in the levels of myristic $\left(\mathrm{C}_{14: 0}\right)$ and palmitic $\left(\mathrm{C}_{16: 0}\right)$ acids observed in Mod-Milk resulted much lower $(-5.93$ and -12.125$)$ than that obtained using a combination of $\mathrm{SO}$ and microalgae (27.6\% for $\mathrm{C}_{140}$ and $18.9 \%$ for $\left.\mathrm{C}_{16: 0}\right)$ [20]. Feeding FO to grazing dairy cows ( 160 or 320 g.day ${ }^{-1}$ ) reduced the $\mathrm{C}_{12: 0}$ concentration in milk without any effect on $\mathrm{C}_{14: 0}$ and $\mathrm{C}_{16: 0}$ [40]. When consumed in excess, these three SFA raise the levels of total plasma cholesterol and the cholesterol associated with low density (LDL) plasma lipoproteins [41].

The reduction of these FA's after PUFA intake is a frequently reported result [31] [42] [43] explained by ruminal biohydrogenation of supplementary PUFA that yields trans-isomers that are inhibitors of key enzymes of mammary lipogenesis such as acetyl-CoA carboxylase [6]. As an associated result, the atherogenic index decreased $(P<0.102)$ from a value of 2.45 in the Reg-Milk to 2.03 in the Mod-Milk (Table 4). However, this $17.23 \%$ reduction resulted much lower than the $44.2 \%$ obtained using a SO-microalgae combination [20] or the $57 \%$ reduction in the AI when grazing cows were supplemented with sunflower and fish oils [22]. Taken together, results obtained help to avoid an excessive consumption of unhealthy FA enhancing the health benefits of Mod-Milk and its dairy products compared to the Reg-Milk.

In the present experiment, milk content of stearic $\left(\mathrm{C}_{18: 0}\right)$ and oleic (cis-9 $\left.\mathrm{C}_{18: 1}\right)$ acids was not affected by oil supply (Table 4) but in the meta-analysis by [28] all PUFA supplements generates similar increases in the content of both FA. In grazing conditions, feeding sunflower seed or sunflower oil enhanced $(+51 \%)$ the concentration and secretion of $\mathrm{C}_{18: 0}$ in milk probably reflecting increased ruminal biohydrogenation of supplementary $\mathrm{C}_{18: 2}$ and VA [22].

In the present experiment (Table 4), milk concentration of stearic acid re-

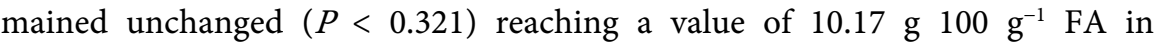

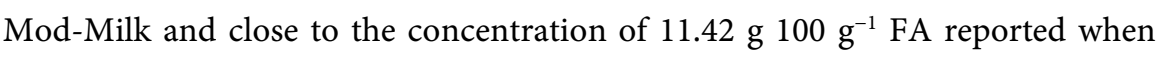
the SO-microalgae supplement was included in the TMR [20].

An increase in milk oleic acid content after the addition of sunflower or SO oils to the ration is a well-documented result [28] [44] [45] also observed when supplementing with linseed oil [28] [46] [47] [48]. In our trial, the presence of this FA remained unchanged $(P<0.504)$ in both milks (Table 4$)$ suggesting that the EPA and DHA contained in FO contributed to attenuate the biohydrogenation of VA to stearic as proposed by [21]. The oleic acid is a component of the so-called "Mediterranean diet" and is fundamentally present in olive oil with beneficial effects on the blood lipid profile and risk factors for cardiovascular diseases [49].

Concentration of MUFA increased by $12 \%$ in the Mod-Milk (Table 4) and those FA has been described to modulate blood pressure, improve insulin sensitivity and regulate circulating glucose levels [49].

In the Reg-Milk, concentration of the unhealthy trans FA such as trans- $9 \mathrm{C}_{18: 1}$ $(0.22 \mathrm{~g} / 100 \mathrm{~g})$ and trans-10 $\mathrm{C}_{18: 1}\left(0.34 \mathrm{~g} 100 \mathrm{~g}^{-1} \mathrm{FA}\right)$ were comparable to those registered in [20]. In the Mod-Milk, concentration ( $100 \mathrm{~g}^{-1} \mathrm{FA}$ ) of trans-9 $\mathrm{C}_{18: 1}$ 
(0.43) was comparable to the value recorded in the previous experiment (0.54) but that of trans-10 $\mathrm{C}_{18: 1}(0.95)$ resulted much lower than the 3.14 value observed with the combination of SO and microalgae [20]. The replacement of corn silage for pasture silage in the present trial could partially explain the difference. The DHA contained in FO (Table 2) may have also contributed to maintaining low levels of trans-10 $\mathrm{C}_{18: 1}$ since the concentration of this trans isomer in milk tended to decrease with the increasing participation of FO mixed to sunflower oil [50]. It can be stated that at the observed concentrations, those trans FA would not present potential risks on the degree of ischemic heart disease to humans [51]. It was postulated that ruminant trans fatty acids, especially concerning the effect on cardiovascular risk, do not possess the same unfavorable effects as industrially produced trans fatty acids [52].

The low content of trans-10 $\mathrm{C}_{18: 1}$ in Mod-Milk is also compatible with the low decrease in milk fat concentration observed (Table 3) and with the lowest reduction of $\mathrm{C}_{12: 0}$ to $\mathrm{C}_{16: 0}$ respect to our previous trial [20]. It was shown that the decrease in milk fat content is negatively correlated to trans-10 $\mathrm{C}_{18: 1}$ levels [32] [53]. A high trans-10 $\mathrm{C}_{18: 1}$ concentration, or its related metabolites like trans-10, cis-12 $\mathrm{C}_{18: 2}$ in milk, has been associated with dysfunctions in lipoprotein lipase (LPL) and stearoyl CoA desaturase (SCD) enzymes involved in milk fat uptake (LPL) and synthesis explaining the decrease in the fatty content of milk [54].

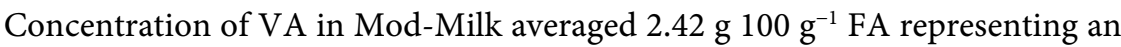

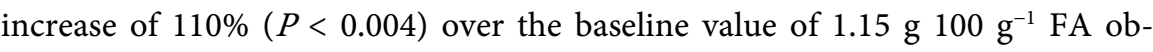
served in the Ref-Milk (Table 4). Those values were close to previously reported in [20]. Natural VA contained in dairy products can exert beneficial anticarcinogenic properties by itself through a direct effect [55] or a mediated effect by its endogenous conversion to rumenic acid (RA) in human tissues at an estimated rate of $20 \%$ [56] by the $\Delta 9$-desaturase activity [57]. The metabolism of VA to RA has been shown to be an effective way to prevent chemically induced cancer in rats [58] and increases the RA bioavailability in tissues [59]. In this and our previous trial [20], the increase in VA induced by PUFA feeding was somehow moderate and should be strengthened.

In the present experiment, FO was included at a low dose $(0.5 \%$ of total DM intake). As it was stated that FO can be reduced at $1 \%$ of total DM intake when it is combined with other sources of lipid substrate [60], the optimal doses of precursors $\left(\mathrm{C}_{18: 2}\right.$ or $\left.\mathrm{C}_{18: 3}\right)$ for CLA synthesis and its combination with FO needs to be explored in grazing and confined dairy cows in order to maximize the milk CLA content and the CLA/trans- $11 \mathrm{C}_{18: 1}$ ratio.

Concentration (g $\left.100 \mathrm{~g}^{-1} \mathrm{FA}\right)$ of cis-9, trans-11 $\mathrm{C}_{18: 2}$ (CLA) increased ( $P<$ 0.039 ) from a baseline value of 0.66 in the Reg-Milk to 1.34 in the Mod-Milk $(+103 \%)$ a value close to that reported in [20] and higher than the average value $(1.02 \pm 0.36 \mathrm{~g} / 100 \mathrm{~g})$ informed in the meta analysis by [28] when dairy cows were supplemented with $\mathrm{SO}$ alone.

In the present trial, the CLA/VA ratio (product/precursor) was 0.36 in both, Reg-Milk and Mod-Milk (Table 4) suggesting that the activity of $\Delta-9$ mammary 
desaturase (generator of CLA from AV) was not changed by oil supply. The average relationship obtained was close to the value of $0.33 \%$ reported by other authors when cows were supplemented with PUFA [33] [54].

The concentration of linoleic acid (cis-9, cis-12 $\mathrm{C}_{18: 2}$ ) remained unchanged ( $P$

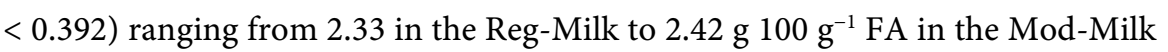
(Table 4$)$ values that were within the normal range (2\% - 3\%) reported by [19].

A decrease $(P<0.004)$ of $14.9 \%$ in the concentration of the $\alpha$-linolenic acid (cis-9, cis-12, cis-15 $\mathrm{C}_{18: 3}$ ) was observed in the Mod-Milk (Table 4) but the ob-

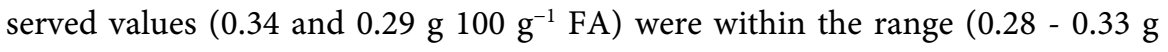
$\left.100 \mathrm{~g}^{-1} \mathrm{FA}\right)$ reported in [61].

The omega-6/omega-3 ratio in the Mod-Milk (7.18) resulted similar $(P<$ $0.129)$ to the 5.98 value observed in the Reg-Milk (Table 4). In Western diets, increased consumption of omega- 6 and decreased levels of omega- 3 has left dietary omega ratios drastically out of balance (15 - 20:1) instead of an optimal of 4:1 [62]. The results obtained suggest that the consumption of Reg-Milk or Mod-Milk (or their derivatives) can contribute to lowering this ratio in the human diet.

Concentration of EPA and DHA in milk did not increase after including FO in the TMR a result that may be explained in part by the low dose of FO used as well as by a high biohydrogenation of these FA in the rumen [6] [21]. It was also postulated that EPA and DHA are present in the cholesteryl esthers and plasmatic phospholipids fractions that are poorly utilized by the mammary gland [21] [63]. The low transfer effectiveness of EPA and DHA from the diet to the milk is consistent with previous findings [21] [40].

\subsection{Nutritional Facts of the Dambo Mofified Type Cheese Compared to the Regular Cheese}

The FA composition of the Mod-DCh was highly correlated $\left(\mathrm{R}^{2}=0.999\right)$ with that Mod-Milk of origin. The Mod-DCh showed differences in FA composition that resulted equivalent to those described for Mod-Milk.

As observed in milk (Table 4), the concentration of total atherogenic FAs $\left(\Sigma \mathrm{C}_{12: 0}-\mathrm{C}_{16: 0}\right)$ tended $(P<0.11)$ to decrease $(-4.65 \%)$ in the Mod-DCh as well as its SF content $(-5.45, P<0.10)$ and AI $(-13.18 \%, P<0.046)$. These results were coupled to a significant increase in healthy FA such as VA, cis-9. trans-11 CLA, MUFA and PUFA with no changes in the $n-6 / n 3$ ratio (Table 5 ). The nutritional information of the Dambo type Cheese per a $30 \mathrm{~g}$ serving is presented in Table 6.

Consuming a portion (30 grams) of the Mod-DCh cheese theoretically implies a $12.1 \%$ lower intake of total fat with a $16.9 \%$ lower consumption of SF compared to the Reg-DCh with a concomitant putative increase $(+72.7 \%)$ in total CLA consumption. As it was already stated, the potential increase in trans fats intake by serving of Mod-DCh is explained by a higher concentration of healthy trans fats such as VA and CLA in the Mod-Milk of origin (Table 4) and in the 
Table 5. Differences in fatty acid (FA) composition between the regular Dambo type cheese (Reg-DCh) and that elaborated with mofified milk (Mod-DCh).

\begin{tabular}{|c|c|c|c|c|}
\hline $\begin{array}{l}\text { Fatty Acid } \\
\text { g } 100 \mathrm{~g}^{-1} \mathrm{FA}\end{array}$ & Reg-DCh & Mod-DCh & $\Delta \%^{(1)}$ & $P<(2)$ \\
\hline $\mathrm{C}_{4: 0}$ & 1.99 & 1.88 & -5.96 & 0.309 \\
\hline $\mathrm{C}_{6: 0}$ & 1.59 & 1.44 & -9.87 & 0.149 \\
\hline $\mathrm{C}_{8: 0}$ & 1.11 & 0.99 & -10.36 & 0.098 \\
\hline $\mathrm{C}_{10: 0}$ & 2.58 & 2.31 & -10.38 & 0.102 \\
\hline $\mathrm{C}_{12: 0}$ & 3.05 & 2.82 & -7.38 & 0.133 \\
\hline $\mathrm{C}_{14: 0}$ & 10.80 & 10.07 & -6.75 & 0.119 \\
\hline $\mathrm{C}_{16: 0}$ & 28.72 & 27.70 & -3.57 & 0.107 \\
\hline$\sum \mathrm{C}_{12: 0-\mathrm{C} 16: 0}$ & 42.57 & 40.59 & -4.65 & 0.114 \\
\hline $\mathrm{C}_{18: 0}$ & 11.96 & 11.01 & -7.92 & 0.010 \\
\hline $\mathrm{C}_{18: 1 \mathrm{t} 9}$ & 0.29 & 0.43 & +52.00 & 0.039 \\
\hline $\mathrm{C}_{18: 1 \mathrm{t} 10}$ & 0.51 & 0.91 & +76.21 & 0.041 \\
\hline $\mathrm{C}_{18: 1} 1$ t11 (vaccenic acid) & 1.43 & 2.42 & +69.32 & 0.001 \\
\hline $\mathrm{C}_{18: 1 \mathrm{c} \text { c9 (oleic acid) }}$ & 21.83 & 22.42 & +2.73 & 0.087 \\
\hline $\mathrm{C}_{18: 2 \mathrm{c} \text { c9 c12 (linoleic acid) }}$ & 2.25 & 2.27 & +1.02 & 0.301 \\
\hline $\mathrm{C}_{18: 3}$ c89 c12 c15 (linolenic acid) & 0.25 & 0.28 & +9.57 & 0.226 \\
\hline $\mathrm{C}_{18: 2 \text { cis-9. trans }-11}$, CLA & 0.72 & 1.24 & +72.69 & 0.013 \\
\hline $\mathrm{C}_{18: 2 \text { cis }-12 \text {, trans }-10}$, CLA & nd & 0.02 & & \\
\hline Total CLA & 0.72 & 1.26 & +72.69 & 0.014 \\
\hline SFA & 65.31 & 61.75 & -5.45 & 0.104 \\
\hline MUFA & 28.34 & 31.09 & +9.69 & 0.010 \\
\hline PUFA & 3.48 & 4.01 & +15.24 & 0.005 \\
\hline Total Omega 3 (n-3) & 0.31 & 0.32 & +5.70 & 0.356 \\
\hline Total Omega 6 (n-6) & 2.46 & 2.43 & -1.11 & 0.061 \\
\hline Atherogenic index & 2.41 & 2.09 & -13.18 & 0.046 \\
\hline$n-6 / n-3$ & 8.06 & 7.55 & -6.39 & 0.309 \\
\hline
\end{tabular}

${ }^{(1)}$ Relative FA changes (\%) compared to values observed in the R-Ch. $(-)=$ decrease, $(+)=$ increase. ${ }^{(2)}$ Student $\mathrm{t}$ Test $\mathrm{t}$ for paired observations.

Table 6. Parameters of nutritional interest in the regular Dambo type cheese (Reg-DCh) and the cheese elaboreted with the modifidied milk (Mod-DCh).

\begin{tabular}{|c|c|c|c|c|}
\hline Parameter & Reg-DCh & Mod-DCh & $\begin{array}{c}\text { Change } \\
(\%)\end{array}$ & $\begin{array}{c}\text { Change } \\
\text { (g per serving) }\end{array}$ \\
\hline Serving & \multicolumn{2}{|c|}{30 grams } & - & - \\
\hline Total fat ${ }^{(1)}$ & 5.973 & 5.250 & -12.1 & -0.723 \\
\hline Total SF${ }^{(1)}$ & 3.673 & 3.052 & -16.9 & -0.621 \\
\hline Total Trans fat ${ }^{(1)}$ & 0.197 & 0.272 & +37.9 & +0.075 \\
\hline Total CLA $^{(1)}$ & 0.040 & 0.070 & +72.7 & +0.029 \\
\hline Total omega-3 $3^{(1)}$ & 0.017 & 0.018 & +3.2 & +0.001 \\
\hline Total omega- $6^{(1)}$ & 0.138 & 0.120 & -13.2 & -0.018 \\
\hline
\end{tabular}

${ }^{(1)}$ Values are expressed in grams per a cheese serving of $30 \mathrm{~g} ;+,-=$ increase or decrease compared to the regular Dambo cheese. 
Mod-DCh (Table 5). It is worth mentioning that the Argentine Alimentary Code declare that the limits for trans FA do not apply to ruminant fat including milk fat.

\subsection{Nutritional Facts of the Modified Yogurt (Mod-Yog) Compared to the Regular Product (Reg-Yog)}

Compared to the Reg-Yog the Mod-Yog made with the Mod-Milk showed differences in its FA composition and in paramaters of nutritional interest (Table 7).

The main differences between the Reg-Yog and the Mod-Yog (Table 7) and

Table 7. Differences in fatty acid (FA) composition between the regular yogurt (Reg-Yog) and that elaborated with the mofified milk (Mod-Yog).

\begin{tabular}{|c|c|c|c|c|}
\hline $\begin{array}{c}\text { Fatty Acid } \\
\left(\mathrm{g} 100 \mathrm{~g}^{-1} \mathrm{FA}\right)\end{array}$ & Reg-Yog & Mod-Yog & $\Delta \%^{(1)}$ & $P<(2)$ \\
\hline $\mathrm{C}_{4: 0}$ & $\mathrm{Nd}$ & $\mathrm{Nd}$ & - & - \\
\hline $\mathrm{C}_{6: 0}$ & nd & nd & - & - \\
\hline $\mathrm{C}_{8: 0}$ & 0.82 & 0.05 & -93.50 & 0.042 \\
\hline $\mathrm{C}_{10: 0}$ & 2.55 & 1.70 & -33.27 & 0.225 \\
\hline $\mathrm{C}_{12: 0}$ & 3.20 & 3.02 & -5.62 & 0.669 \\
\hline $\mathrm{C}_{14: 0}$ & 11.28 & 10.80 & -4.24 & 0.408 \\
\hline $\mathrm{C}_{16: 0}$ & 29.69 & 29.01 & -2.31 & 0.285 \\
\hline$\sum \mathrm{C}_{12: 0-\mathrm{C} 16: 0}$ & 44.17 & 42.83 & -3.04 & 0.159 \\
\hline $\mathrm{C}_{18: 0}$ & 12.33 & 11.39 & -7.66 & 0.196 \\
\hline $\mathrm{C}_{18: 1 \mathrm{t} 9}$ & 0.34 & 0.52 & +53.50 & 0.142 \\
\hline $\mathrm{C}_{18: 1 \mathrm{t} 10}$ & 0.52 & 1.00 & +92.73 & 0.037 \\
\hline $\mathrm{C}_{18: 1 \mathrm{t} 11 \text { (vaccenic acid) }}$ & 1.66 & 2.54 & +52.71 & 0.069 \\
\hline $\mathrm{C}_{18: 1 \text { c9 (oleic acid) }}$ & 23.00 & 23.73 & +3.20 & 0.371 \\
\hline $\mathrm{C}_{18: 2 \text { c9 c12 (linoleic acid) }}$ & 2.35 & 2.54 & +7.85 & 0.013 \\
\hline $\mathrm{C}_{18: 3 \text { c89 c12 c15 (linolenic acid) }}$ & 0.30 & 0.31 & +3.07 & 0.664 \\
\hline $\mathrm{C}_{18: 2 \text { cis-9, trans } 11}$, CLA & 0.72 & 1.20 & +66.14 & 0.031 \\
\hline $\mathrm{C}_{18: 2 \text { cis-12, trans }-10, \mathrm{CLA}}$ & $\mathrm{Nd}$ & 0.02 & & \\
\hline Total CLA & 0.72 & 1.22 & +68.73 & 0.032 \\
\hline SFA & 63.37 & 59.49 & -6.12 & 0.067 \\
\hline MUFA & 30.14 & 33.03 & +9.59 & 0.082 \\
\hline PUFA & 3.65 & 4.33 & +18.76 & 0.022 \\
\hline Total Omega 3 (n-3) & 0.36 & 0.39 & +6.52 & 0.198 \\
\hline Total Omega 6 (n-6) & 2.56 & 2.73 & +6.42 & 0.025 \\
\hline Atherogenic index & 2.36 & 2.08 & -11.78 & 0.145 \\
\hline$n-6 / n-3$ & 7.04 & 7.03 & -0.07 & 0.98 \\
\hline
\end{tabular}

${ }^{(1)}$ Relative FA changes (\%) compared to values observed in the Reference yogurt, $(-)=$ decrease, $(+)=$ increase. ${ }^{(2)}$ Student $t$ Test $t$ for paired observations. 
their healthy implications are equivalent to those described for the Mod-Milk of origin (Table 4). The decrease in the total SF content $(P<0.067)$ and the tendency to a lower atherogenic index $(-11.78 \%, P<0.15)$ coupled with the observed increase in VA (+52.7\%), total CLA (+68.7\%), MUFA (+9.6\%) and PUFA $(+18.8 \%)$ improved the healthy value of the Mod-Yog. The nutritional information per serving of 178 grams of yogurt is presented in Table 8.

Consuming a portion of the Mod-Yog (178 grams) theoretically corresponds to a $13 \%$ increase in total fat consumption with a concomitant increase of SF intake of $6.3 \%$ compared to a serving of the Reg-Yog but total CLA intake would result enhanced in 69.4\%. As observed for the modified Dambo type cheese (Table 7), the increase in the consumption of trans fats was at the expense of a higher concentration of healthy trans FA such as VA and CLA in both, mofified milk (Table 4) and Mod-Yog (Table 7). As it was already mentioned, the Argentine Alimentary Code excludes trans fats from ruminants, including milk fat.

\subsection{Simple Economic Analysis}

Fixing a value of US $\$ 0.30$ per liter of milk produced for the farmer and at the average milk yield obtained of 34.69 liters $\mathrm{cow}^{-1} \cdot \mathrm{day}^{-1}$ (Table 3 ), the direct income is US $\$ 10.41 \mathrm{cow}^{-1}$. day ${ }^{-1}$ being the cost without oil of US $\$ 4.942$. Under these conditions, the cost of feeding represents $47.49 \%$ of the milk produced with a margin over food expenses estimated at US $\$ 5.46 \mathrm{cow}^{-1} \cdot \mathrm{day}^{-1}$. Taken into account the SO (US $\$ 0.755 \mathrm{~kg}^{-1}$ ) and FO (US $\$ 4.114 \mathrm{~kg}^{-1}$ ) prices, it can be estimated that the feeding-cost to produce the Mod-Milk increases up to US $\$ 6.07 \mathrm{cow}^{-1} \cdot$ day $^{-1}(+22.8 \%)$ at the oil-dose used. Under these conditions, the cost of feeding represented 58.33\% of the produced milk with a margin over food expenses estimated in US $\$ 4.34$ $\mathrm{cow}^{-1}$. The feeding costs after the inclusion of soybean and fish oils to the ration of cows at different levels of milk production is shown in Table 9.

Using inputs-prices from Table 1, it can be estimated that below a production of 20 liters $\mathrm{cow}^{-1} \cdot \mathrm{day}^{-1}$ the margin over food expenses to produce the Mod-Milk begins to be negative (Figure 1).

Table 8. Parameters of nutritional interest in the regular yogurt (Reg-Yog) and the yogurt elaborated with the modifidied milk (Mod-Yog).

\begin{tabular}{ccccc}
\hline Parameter & Reg-Yog & Mod-Yog & $\begin{array}{c}\text { Change } \\
(\%)\end{array}$ & $\begin{array}{c}\text { Change } \\
\text { (g per serving) }\end{array}$ \\
\hline Serving & \multicolumn{2}{c}{178 grams } & - & - \\
Total fat $^{(1)}$ & 5.676 & 6.426 & +13.21 & +0.75 \\
Total SF $^{(1)}$ & 3.387 & 3.599 & +6.28 & +0.213 \\
Total Trans fat $^{(1)}$ & 0.207 & 0.346 & +67.32 & +1.139 \\
Total CLA $^{(1)}$ & 0.038 & 0.065 & +69.44 & +0.027 \\
Total omega-3 $^{(1)}$ & 0.019 & 0.021 & +8.33 & 0.002 \\
Total omega-6 $^{(1)}$ & 0.137 & 0.165 & +20.75 & 0.028 \\
\hline
\end{tabular}

${ }^{(1)}$ Values are expressed in grams per yogurt serving; +, - = increase or decrease compared to the Reg-Yog. 
Table 9. Economic analysis of feeding costs following the inclusion of soybean oils $(0.840$ $\left.\mathrm{kg} \mathrm{cow}^{-1} \cdot \mathrm{day}^{-1}\right)$ and fish oils $(0.115 \mathrm{~kg} / \mathrm{cow} /$ day $)$ in the ration at different levels of milk production.

\begin{tabular}{cccc}
\hline $\begin{array}{c}\text { Milk } \\
\text { cow }^{-1} \cdot \text { day }^{-1}\end{array}$ & $\begin{array}{c}\text { Income } \\
\left(\text { US }^{(1)} \text { cow }^{-1} \cdot \text { day }^{-1}\right.\end{array}$ & $\begin{array}{c}\text { Feeding cost without oils } \\
\text { (\% produced milk) }\end{array}$ & $\begin{array}{c}\text { Feeding cost including oils } \\
\text { (\% produced milk) }\end{array}$ \\
\hline 15 & 4.5 & 109.83 & 134.89 \\
20 & 6 & 82.37 & 101.17 \\
25 & 7.5 & 65.90 & 80.94 \\
30 & 9 & 54.91 & 67.45 \\
35 & 10.5 & 47.07 & 57.81 \\
\hline
\end{tabular}

${ }^{(1)}$ One liter of milk $=0.30$ US\$.

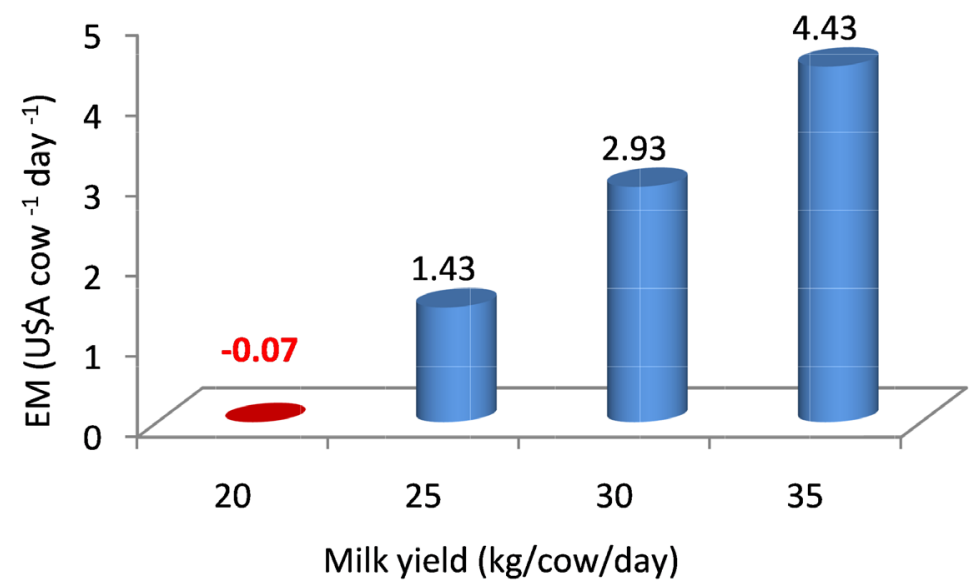

Figure 1. Economic margin above food costs (EM) to produce the modified milk according to milk production.

\section{Conclusion}

Supplementation with PUFA contained in SO and FO induced healthy differences in milk FA profile between the regular milk and the modified milk which improves its nutritional value and that of Dambo type cheese and yogurt made with it. This improvement involved a reduction in SF content and the increase in healthy fatty acids such as VA and natural CLA. Raw milk, Dambo type cheese and yogurt showed adequate values for the omega $6 / 3$ ratio. The properties observed in the modified CLA milk were recovered in the cheese and yogurt made with it. The increase in total trans fat values was the consequence of the higher concentrations of healthy trans FA like VA and CLA whereas the unhealthy (trans-9 and trans-10 $\mathrm{C}_{18: 1}$ ) remained in values considered harmless to human health.

\section{Acknowledgements}

This work was partially supported by the National Agency of Research and Innovation (ANII), Uruguay Republic (Project Milk Talar CLA, IDI_X_2016_1_131308,

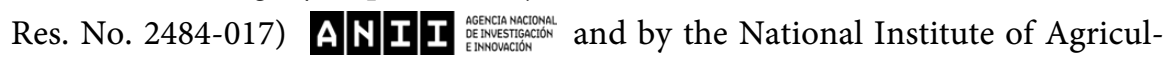


tural Technology (INTA, Argentina) INTA

We thank the staff of Tambo Talar for the collaboration in animal care and management.

\section{Conflicts of Interest}

The authors declare no conflicts of interest regarding the publication of this paper.

\section{References}

[1] Hu, F.B., Manson, J.E. and Willet, W.C. (2001) Types of Dietary Fat and Risk Coronary Heart Disease: A Critical Review. Journal American College Nutrition, 20, 5-19. https://doi.org/10.1080/07315724.2001.10719008

[2] Siri-Tarino, P.W., Sun, Q., Hu, F.B. and Krauss, R.M. (2010). Saturated Fatty Acids and Risk of Coronary Heart Disease: Modulation by Replacement Nutrients. Current Atherosclerosis Reports, 12, 384-390.

https://doi.org/10.1007/s11883-010-0131-6

[3] Livingstone, K.M., Lovegrove, J.A. and Givens, D.I. (2012) The Impact of Substituting SFA in Dairy Products with MUFA or PUFA on CVD Risk: Evidence from Human Intervention Studies. Nutrition Research Reviews, 25, 193-206.

https://doi.org/10.1017/S095442241200011X

[4] Ulbritch, T.L. and Southgate, D.A.T. (1991) Coronary Heart Disease: Seven Dietary Factors. The Lancet, 338, 985-992. https://doi.org/10.1016/0140-6736(91)91846-M

[5] Stanton, C., Murphy, J., McGrath, E. and Devery, R. (2003) Animal Feeding Strategies for Conjugates Linoleic Acid Enrichment of Milk. In: Sebedio, J.L., Christie, W.W. and Adloff, R., Eds., Advances in Conjugated Linoleic Acid in Food, AOCS Press, Champaign, 123-145.

[6] Chilliard, Y. and Ferlay, A. (2004) Dietary Lipids and Forages Interactions on Cows and Goat Milk Acid Composition and Sensory Properties. Reproduction Nutrition Development, 44, 467-492. https://doi.org/10.1051/rnd:2004052

[7] Larson, S.C., Bergkvist, L. and Wolk, A. (2005) High-Fat Dairy Food and Conjugated Linoleic Acid Intakes in Relation to Colorectal Cancer Incidence in the Swedish Mammography Cohort. American Journal of Clinical Nutrition, 82, 894-900. https://doi.org/10.1093/ajen/82.4.894

[8] Bhattacharyaa, A., Banua, J., Rahmana, M., Causeyb, J. and Fernandes, G. (2006) Biological Effects of Conjugated Linoleic Acids in Health and Disease. Journal of Nutritional Biochemistry, 17, 789-810. https://doi.org/10.1016/j.jnutbio.2006.02.009

[9] De La Torre, A., Debiton, E., Juanéda, P., Durand, D., Chardigny, J.M., Barthomeuf, C., Bauchart, D. and Gruffat, D. (2006) Beef Conjugated Linoleic Acid Isomers Reduce Human Cancer Cell Growth Even When Associated with Other Beef Fatty Acids. British Journal of Nutrition, 95, 346-352. https://doi.org/10.1079/BJN20051634

[10] Ryder, J.W., Portocarrero, C.P., Song, X.M., et al. (2001) Isomer-Specific Antidiabetic Properties of Conjugated Linoleic Acid. Improved Glucose Tolerance, Skeletal Muscle Insulin Action, and UCP-2 Gene Expression. Diabetes, 50, 1149-1157. https://doi.org/10.2337/diabetes.50.5.1149

[11] Houseknecht, K.L., Vanden Heuvel, J.P., Moya-Camarena, S.Y., et al. (1998) Dietary Conjugated Linoleic Acid Normalizes Impaired Glucose Tolerance in the Zucker Diabetic Fatty fa/fa Rat. Biochemical and Biophysical Research Communications, 
244, 678-682. https://doi.org/10.1006/bbrc.1998.8303

[12] Lee, K.N., Kritchevsky, D. and Pariza, M.W. (1994) Conjugated Linoleic Acid and Atherosclerosis in Rabbits. Atherosclerosis, 108, 19-25. https://doi.org/10.1016/0021-9150(94)90034-5

[13] Ha, Y.L., Storkson, J. and Pariza, M.W. (1990) Inhibition of Benzo(a) Pyreneinduced Mouse Forestomach Neoplasia by Conjugated Dienoic Derivatives of Linoleic Acid. Cancer Research, 50, 1097-1101.

[14] Ip, C., Banni, S., Agioni, E., Carta, G., MCGinley, J., Thompson, H.J., Barbano, D. and Bauman, D. (1999) Conjugated Linoleic Acid-Enriched Butter Fat Alters Mammary Gland Morphogenesis and Reduces Cancer Risk in Rats. Journal of $\mathrm{Nu}$ trition, 129, 2135-2142. https://doi.org/10.1093/jn/129.12.2135

[15] Watkins, B.A. and Li, Y. (2003) CLA in Functional Food: Enrichment of Animal Products. In: Sébédio, J.L., Christie, W.W. and Adloff, R., Eds., Advances in Conjugated Linoleic Acid in Food, Volume 2, AOCS Press, Champaign, 174-188. https://doi.org/10.1201/9781439822166.ch11

[16] Miller, C.C., Park, Y., Pariza, M.W. and Cook, M.E. (1994) Feeding Conjugated Linoleic Acid to Animals Partially Overcomes Catabolic Responses Due to Endotoxin Injection. Biochemical and Biophysical Research Communication, 198, 1107-1112. https://doi.org/10.1006/bbrc.1994.1157

[17] Yang, M. and Cook, M.E. (2003) Dietary Conjugated Linoleic Acid Decreased Cachexia, Macrophage Tumor Necrosis Factor-Alpha Production, and Modifies Splenocyte Cytokines Production. Experimental Biological Medicine, 228, 51-58. https://doi.org/10.1177/153537020322800107

[18] Smit, L.A., Baylin, A. and Campos, H. (2010) Conjugated Linoleic Acid in Adipose Tissue and Risk of Myocardial Infarction. American Journal of Clinical Nutrition, 92, 34-40. https://doi.org/10.3945/ajcn.2010.29524

[19] Chilliard, Y., Gasser, G., Enjalbert, F., Ferlay, A., Bocquier, F. and Schmidely, P.H. (2007) Conferencia: Resultados Recientes Sobre los Efectos de la Alimentación en la Composición en Acidos Grasos de la Leche de Vaca, Cabra y Oveja. Revista Argentina de Producción Animal, 27, 197-213.

[20] Gagliostro, G.A., Antonacci, L.E., Pérez, C.D., Rossetti, L. and Carabajal, A. (2018) Improving the Quality of Milk Fatty Acid in Dairy Cows Supplemented with Soybean Oil and DHA-Micro Algae in a Confined Production System. Agricultural Sciences, 9, 1115-1130. https://doi.org/10.4236/as.2018.99078

[21] Chilliard, Y., Ferlay, A., Mansbridge, R.M. and Doreau, M. (2000) Ruminant Milk Fat Plasticity: Nutritional Control of Saturated, Polyunsaturated, Trans and Conjugated Fatty Acids. Annales de Zootechnie, 49, 181-205. https://doi.org/10.1051/animres:2000117

[22] Gagliostro, G.A., Garciarena, D.A., Rodriguez, M.A. and Antonacci, L.E. (2017) Feeding Polyunsaturated Supplements to Grazing Dairy Cows Improve the Healthy Value of Milk Fatty Acids. Agricultural Sciences, 8, 759-782. https://doi.org/10.4236/as.2017.88057

[23] Luna, P., Juárez, M. and de la Fuente, M.A. (2005) Validation of a Rapid Milk Fat Separation Method to Determine the Fatty Acid Profile by Gas Chomatography. Journal of Dairy Science, 88, 3399-3381. https://doi.org/10.3168/jds.S0022-0302(05)73021-6

[24] ISO-IDF (2002) Milk Fat-Preparation of Fatty Acid Methyl Esters. International Standard ISO 15884-IDF 182:2002. International Dairy Federation, Brussels.

[25] Gagliostro, G.A. and Chilliard, Y. (1992) Use of Protected Lipids in Dairy Cow Nu- 
trition. I. Effects on the Production and Composition of Milk, and on Intake of Dry Matter and Energy. Revista Argentina de Producción Animal, 12, 1-15.

[26] Schroeder, G.F., Gagliostro, G.A., Bargo, F., Delahoy, J.E. and Muller, L.D. (2004) Effects of Fat Supplementation on Milk Production and Composition by Dairy Cows on Pasture: A Review. Livestock Production Science, 86, 1-18. https://doi.org/10.1016/S0301-6226(03)00118-0

[27] Morand-Fehr, P., Chilliard, Y. and Bas, P. (1986) Impact of Including Fats in the Ration on Yield and Composition of Ruminant Milk. Institut National de la Recherche Agronomique, 64, 59-72.

[28] Glasser, F., Ferlay, A. and Chilliard, Y. (2008) Oilseed Lipid Supplements and Fatty Acid Composition of Cow Milk: A Meta-Analysis. Journal of Dairy Science, 91, 4687-4703. https://doi.org/10.3168/jds.2008-0987

[29] Dhiman, T.R., Satter, L.D., Pariza, M.W., Galli, M.P., Albright, K. and Tolosa, M.X. (2000) Conjugated Linoleic Acid (CLA) Content of Milk from Cows Offered Diets Rich in Linoleic and Linolenic Acid. Journal of Dairy Science, 83, 1016-1027. https://doi.org/10.3168/jds.S0022-0302(00)74966-6

[30] Alzahal, O., Odongo, N.E., Mutsvanqwa, T., Or-Rashid, M.M., Duffield, T.F., Baqq, R., Dick, P., Vessie, G. and McBride, B.W. (2008) Effects of Monensin and Dietary Soybean Oil on Milk Fat Percentage and Milk Fatty Acid Profile in Lactating Dairy Cows. Journal of Dairy Science, 91, 1166-1174. https://doi.org/10.3168/jds.2007-0232

[31] Huang, Y., Schoonmaker, J.P., Bradford, B.J. and Beitz, D.C. (2008) Response of Milk Fatty Acid Composition to Dietary Supplementation of Soy Oil, Conjugated Linoleic Acid, or Both. Journal of Dairy Science, 91, 260-270. https://doi.org/10.3168/jds.2007-0344

[32] Piperova, L.L., Teter, B.B., Bruckental, I., Sampugna, J., Mills, S.E., Yurawecz, M.P., Fritsche, J., Ju, K. and Erdman, R.A. (2000) Mammary Lipogenic Enzyme Activity, Trans Fatty Acids and Conjugated Fatty Acids Are Altered in Lactating Dairy Cows Fed a Milk-Fat Depressing Diet. Journal of Nutrition, 130, 2568-2574. https://doi.org/10.1093/jn/130.10.2568

[33] Griinari, J.M. and Bauman, D.E. (1999) Biosynthesis of Conjugated Linoleic Acid and Its Incorporation into Meat and Milk in Ruminants. In: Yurawecz, M.P., Mossoba, M.M., Kramer, J.K.G., Pariza, M.W. and Nelson, G.J., Eds., Advances in Conjugated Linoleic Acid Research, AOCS Press, Champaign, 180-200.

[34] Martinez, M.G. (2010) Modulation of the Fatty Acid Composition of Bovine and Caprine Milk through Supplementation with Soybean and Fish Oil. Master Science Thesis, Faculty of Agrarian Sciences, National University of Mar de Plata, Argentina, $130 \mathrm{p}$.

[35] Bargo, F., Muller. L.D., Kolver, E.S. and Delahoy, J.E. (2003) Invited Review: Production and Digestion of Supplemented Dairy Cows on Pasture. Journal of Dairy Science, 86, 1-42. https://doi.org/10.3168/jds.S0022-0302(03)73581-4

[36] Wu, Z. and Huber, J.T. (1994) Relationship between Dietary Fat Supplementation and Milk Protein Concentration in Lactating Cows: A Review. Livestock Production Science, 39, 141-155. https://doi.org/10.1016/0301-6226(94)90180-5

[37] Storry, J.E. (1981) The Effect of Dietary Fat on Milk Composition. In: Haresing, W., Ed., Recent Advances in Animal Nutrition, Butterworths, London, 3-33. https://doi.org/10.1016/B978-0-408-71014-5.50005-4

[38] Dunkley, W.L., Smith, N.E. and Franke, A.A. (1977) Effect of Feeding Protected Tallow on Composition of Milk and Milk Fat. Journal of Dairy Science, 60, 
1863-1869. https://doi.org/10.3168/jds.S0022-0302(77)84116-7

[39] Parodi, P.W. (1999) Conjugated Linoleic Acid and Other Anticarcinogenic Agents of Bovine Milk Fat. Journal of Dairy Science, 82, 1339-1349. https://doi.org/10.3168/jds.S0022-0302(99)75358-0

[40] Rego, O.A., Rosa, H.J.D., Portugal, P., Cordeiro, R., Borba, A.E.S., Vouzela, C.M. and Bessa, R.J.B. (2005) Influence of Dietary Fish Oil on Conjugated Linoleic Acid, Omega-3 and Other Fatty Acid in Milk Fat from Grazing Dairy Cows. Livestock Production Science, 95, 27-33. https://doi.org/10.1016/j.livprodsci.2004.11.040

[41] Schrezenmeir, J. and Jagla, A. (2000) Milk and Diabetes. Journal of the American College of Nutrition, 19, 176-190. https://doi.org/10.1080/07315724.2000.10718087

[42] AbuGhazaleh, A. and Jenkins, T.C. (2004) Short Communication: Decosahexaenoic Acid Promotes Vaccenic Acid Accumulation in Mixed Rumen Cultures When Incubated with Linoleic Acid. Journal of Dairy Science, 87, 1047-1050. https://doi.org/10.3168/jds.S0022-0302(04)73250-6

[43] Zheng, H.C., Liu, J.X., Yao, J.H., Yuan, Q., Ye, H.W., Ye, J.A. and Wu, Y.M. (2005) Effects of Dietary Sources of Vegetable Oils on Performance of High-Yielding Lactating Cows and Conjugated Linoleic Acids in Milk. Journal of Dairy Science, 88, 2037-2042. https://doi.org/10.3168/jds.S0022-0302(05)72880-0

[44] Rego, O.A., Alves, S.P., Antunes, L.M.S., Rosa, H.J.D., Alfaia, C.F.M., Prates, J.A.M., Cabrita, A.R.J., Fonseca, A.J.M. and Bessa, R.J.B. (2009) Rumen Biohydrogenation-Derived Fatty Acids in Milk Fat from Grazingdairy Cows Supplemented with Rapeseed, Sunflower, or Linseed Oils. Journal of Dairy Science, 92, 4530-4540. https://doi.org/10.3168/jds.2009-2060

[45] Cruz-Hernandez, C., Kramer, J.K.G., Kennelly, J.J., Glimm, D.R., Sorensen, B.M., Okine, E.K., Goonewardene, L.A. and Weselake, R.J. (2007) Evaluating the Conjugated Linoleic Acid and Trans 18:1 Isomers in Milk Fat of Dairy Cows Fed Increasing Amounts of Sunflower Oil and a Constant Level of Fish Oil. Journal of Dairy Science, 90, 3786-3801. https://doi.org/10.3168/jds.2006-698

[46] Bu, D.P., Wang, J.G., Dhiman, T.R. and Liu, S.J. (2007) Effectiveness of Oils Rich in Linoleic and Linolenic Acids to Enhance Conjugated Linoleic Acid in Milk from Dairy Cows. Journal of Dairy Science, 90, 998-1007. https://doi.org/10.3168/jds.S0022-0302(07)71585-0

[47] Chilliard, Y., Martin, C., Rouel, J. and Doreau, M. (2009) Milk Fatty Acids in Dairy Cows Fed Whole Crude Linseed, Extruded Linseed, or Linseed Oil, and Their Relationship with Methane Output. Journal of Dairy Science, 92, 5199-5211. https://doi.org/10.3168/jds.2009-2375

[48] Hurtaud, C., Faucon, F., Couvreur, S. and Peyraud, J.L. (2010) Linear Relationship between Increasing Amounts of Extruded Linseed in Dairy Cow Diet and Milk Fatty Acid Composition and Butter Properties. Journal of Dairy Science, 93, 1429-1443. https://doi.org/10.3168/jds.2009-2839

[49] Gullingham, L.G., Harris-Janz, S. and Jones, P.J. (2011) Dietary Monounsaturated Fatty Acids Are Protective against Metabolic Syndrome and Cardiovascular Disease Risk Factors. Lipids, 46, 2019-2228. https://doi.org/10.1007/s11745-010-3524-y

[50] Palmquist, D. and Griinari, M. (2006) Milk Fatty Acid Composition in Response to Reciprocal Combinations of Sunflower and Fish Oils in the Diet. Animal Feed Science and Technology, 131, 358-369. https://doi.org/10.1016/j.anifeedsci.2006.05.024

[51] Roy, A., Chardigny, J.M., Bauchart, D., Ferlay, A., Lorenz, S., Durand, D., Duffart, D., Faulconnier, Y., Sébédio, J.L. and Chilliard, Y. (2007) Butters Rich Either in 
Trans-10-C18:1 or in Trans-11-C18:1 plus cis-9-trans11 CLA Differentially Affect Plasma Lipids and Aortic Fatty Streak in Experimental Atherosclerosis in Rabbits. Animal, 1, 467-476. https://doi.org/10.1017/S175173110770530X

[52] Department of Health (1994) Nutritional Aspects of Cardiovascular Disease, Report of the Cardiovascular Review Group of the Committee of Medical Aspects of Food Policy (COMA). Report No. 46. His Majesty's Stationery Office, London.

[53] Antonacci, L.E., Gagliostro, G.A., Cano, A.V. and Bernal, C.A. (2017) Effects of Feeding Combinations of Soybean and Linseed Oils on Productive Performance and Milk Fatty Acid Profile in Grazing Dairy Cows. Agricultural Sciences, 8, 984-1002. https://doi.org/10.4236/as.2017.89072

[54] Griinari, J.M. and Bauman, D.E. (2006) Milk Fat Depression: Concepts, Mechanisms and Management Applications. In: Sjersen, K., Hvelplund, T. and Nielsen, M.O., Eds., Ruminant Physiology: Digestion, Metabolism and Impact of Nutrition on Gene Expression, Immunology and Stress, Wageningen Academic Publishers, Wageningen, 389-417.

[55] Awad, A.B., Hermann, T., Fink, C.S. and Horvath, P.J. (1995) 18:1 n7 Fatty Acids Inhibit Growth and Decreased Inositol Phosphate Release in HT-29 Cells Compared to n-9 Fatty Acids. Cancer Letters, 91, 55-61. https://doi.org/10.1016/0304-3835(95)03725-C

[56] Turpeinen, A.M., Mutanen, M., Aro, A., Salminen, I., Basu, S., Palmquist, D.L. and Griinari, J.M. (2002) Bioconversion of Vaccenic Acid to Conjugated Linoleic Acid in Humans. American Journal of Clinical Nutrition, 76, 504-510. https://doi.org/10.1093/ajcn/76.3.504

[57] Parodi, P.W. (2003) Conjugated Linoleic Acid in Food. In: Sebedio, J.L., Christie, W.W. and Adloff, R., Eds., Advances in Conjugated Linoleic Acid in Food, Volume 2, AOCS Press, Champaign, 101-122. https://doi.org/10.1201/9781439822166.ch8

[58] Banni, S., Angioni, E., Murru, E., Carta, G., Melis, M.P., Bauman, D., Dong, Y. and Ip, C. (2001) Vaccenic Acid Feeding Increases Tissue Levels of Conjugated Linoleic Acid and Suppreses Development of Remalignant Lesions in Rat Mammary Gland. Nutrition and Cancer, 41, 91-97. https://doi.org/10.1080/01635581.2001.9680617

[59] Siurana, A. and Calsamiglia, S. (2016) A Metaanalysis of Feeding Strategies to Increase the Content of Conjugated Linoleic Acid (CLA) in Dairy Cattle Milk and the Impact on Daily Human Consumption. Animal Feed Science and Technology, 217, 13-26. https://doi.org/10.1016/j.anifeedsci.2016.04.013

[60] Ramaswamy, N., Baer, R.J., Schingoethe, D.J., Hippen, A.R., Kasperson, K.M. and Whitlock, L.A. (2001) Composition and Flavor of Milk and Butter from Cows Fed Fish Oil, Extruded Soybeans, or Their Combination. Journal of Dairy Science, 84, 2144-2151. https://doi.org/10.3168/jds.S0022-0302(01)74659-0

[61] Antonacci, L.E., Rodríguez, A., Castelli, L., Zampatti, M., Castañeda, R., Ceaglio, J. and Gagliostro, G.A. (2013) Supplementation with a Blend of Vegetable Oils and the Fatty Acid Profile of Bovine Milk. Revista Argentina de Producción Animal, 33, 158.

[62] Mensink, R.P., Zock, P.L., Kester, A.D. and Katan, M.B. (2003) Effects of Dietary Fatty Acids and Carbohydrates on the Ratio of Serum Total to HDL Cholesterol. American Journal of Clinical Nutrition, 77, 1146-1155. https://doi.org/10.1093/ajcn/77.5.1146

[63] Offer, N.W., Marsden, M., Dixon, J., Speake, B.K. and Thacker, F.E. (1999) Effect of Dietary Fat Supplements on Levels of N-3 Polyunsaturated Fatty Acids, Trans Acids and Conjugated Linoleic Acid in Bovine Milk. Journal of Animal Science, 69, 613-625. https://doi.org/10.1017/S135772980005147X 